\title{
Cytotaxonomic studies in African Asclepiadaceae
}

\author{
F. ALBERS*
}

\author{
ABSTRACT
}

The family Asclepiadaceae of about 290 genera is a homogeneous complex with complicated flower-structure. Little cytological data are available on the approximately 3000 species in the family. The best studied subtribe is the Ceropegiinae (sensu Schumann, 1895) including the Stapelieae (as presently recognized) with its dominantly succulent members. Exactly half of the species are known karyologically. The basic chromosome number in the family is $\mathrm{x}=11$ and in most of the genera polyploid taxa are also to be found. The small size of the chromosomes makes individual identification very difficult and they form a graded series with very slight morphological differences. C-banding permits identification of heterochromatic regions; they all take up near centromeric positions. Therefore, studies aimed at an analysis of relationships with the aid of chromosome morphology on a lower taxonomic level, will hardly be possible. In so far as morphological characters of the inflorescence are concerned, diploid species of the genus Caralluma seem to form a species centre in South Arabia/East Africa.

\section{$R E ́ S U M E ́$}

\section{ÉTUDES CYTOTAXONOMIQUES CHEZ LES ASCLÉPIADACEES AFRICAINES}

La famille des Asclépiadacées, comptant environ 290 genres, est un complexe homogène avec une structure florale compliquée. Peu de données cytologiques sont disponibles sur les quelque 3000 espèces de la famille. La sous-tribu la mieux étudiée est celle des Céropégïnées (sensu Schumann, 1895) incluant les Stapéliées avec la plupart de ses membres succulents. Exactement la moitié des espèces sont connues caryologiquement. Le nombre de chromosomes de base dans la famille est $x=11$ et dans la plupart des genres, des taxons polyploides peuvent aussi se recontrer. La petite taille des chromosurnes rend l'identification individuelle très difficile et ils forment une série progressive avec de très faibles différences morphologiques. Le C-banding permet l'identification des régions hétérochromatiques; elles se situent toutes, à proximité du centromère. Par conséquent, les études qui ont pour but d'analyser les affinités à l'aide de la morphologie du chromosome à un niveau taxonomique inférieure, seront difficilement possibles. Pour autant que les caractères morphologiques de l'inflorescence soient concernés, les espèces diploïdes de genre Caralluma semblent former un centre de speciation dans le Sud de l'Arabie et l'Afrique de l'Est.

The basic scheme for the infrafamilial classification of Asclepiadaceae was laid down by Robert Brown as early as 1811. Most workers have subsequently accepted this classification with few deviations, but names and taxonomic ranks have changed considerably.

Schumann's (1895) systematic classification, based directly on Brown's original key to the genera of Asclepiadaceae, is used in the classification adopted in Table 1. The few chromosome numbers published in the various subtribes indicate that little cytological data are available for taxa distributed throughout the world, except for some more detailed studies of the succulent members of the subtribe Ceropegiinae. Of the 290 genera with about 3000 species, only 342 species in 52 genera are known karyologically, i.e. only $11 \%$ of the species. The basic chromosome number in the family is $\mathrm{x}=11$ and the literature reveals few numbers deviating from this, such as 10 and 12 .

Cytotaxonomically, the best-studied subtribe is Ceropegiinae, which is, with few exceptions, well characterized by pollinia with a special germination area and winged caudicles (Schill \& Jäckel, 1978). It is represented in southern Africa by members of the genera Orthanthera Wight, Brachystelma R. Br., Dichaelia Harvey, Ceropegia L., Riocreuxia Decne, and by an allied group formed by the stapeliads. In

"Botanisches Institut der Universität Kiel, Biologiezentrum, Olshausentrasse 40-60, $2300 \mathrm{Kiel}$, West Germany. the last-mentioned group, with exclusively succulent-stemmed members, karyological work was started by Reese in 1967 . The data given in Table 2 are from the later publications of Reese (1971) and the present author $(1974,1975,1976,1977,1981)$. The present taxonomic situation proposed by Leach (1975, 1978, 1980) merits comment. Previous classification in stapeliads has been based mainly on floral characters, particularly those of the corona, the inner part of the flower. The division on coronal characters has resulted in a most unsatisfactory situation, particularly at sectional and generic level. We are now aware that the corona is a very variable structure, and its usefulness as a major character in taxonomic work is therefore diminished. In an effort to obtain a more natural classification, particularly at generic level, Leach has paid more attention to vegetative characters such as the form of the stems and arrangement of the leaves. The result is that some genera such as Orbeopsis, Pachycymbium and Orbeanthus have had to be set up, or reinstated such as Orbea and Haworth's long-forgotten genus Tridentea. Other genera, for example Echidnopsis, Hoodia, Huernia and Piaranthus are readily distinguishable by vegetative and floral characters.

Each of the 11 genera mentioned in Table 2 contains more than 10 species; the largest with 120 species is the genus Caralluma. In the remaining 11 genera there are 47 species. The chromosome numbers of exactly half the species are known. In many of the taxa only one plant could be studied. Investigations in some species have shown that 
TABLE 1.- Taxa of the Asclepiadaceae with known chromosome numbers

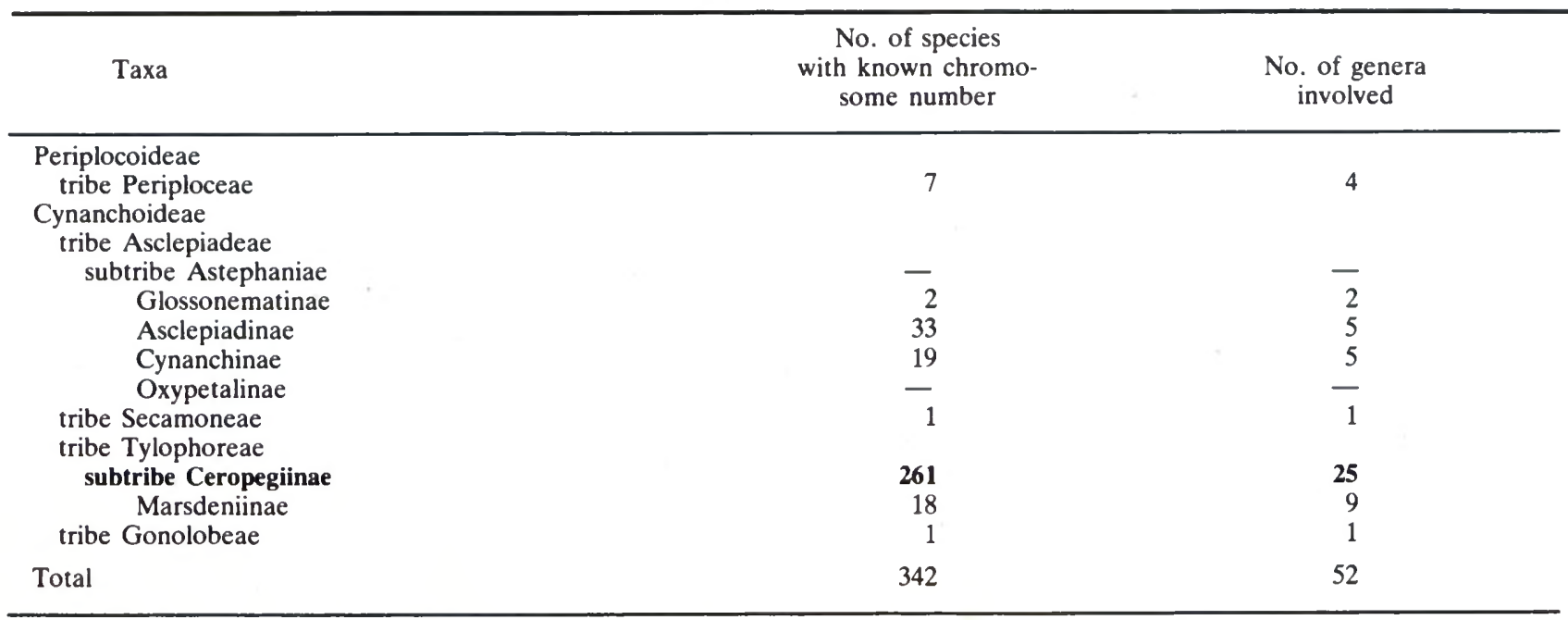

TABLE 2.-Genera of the stapeliads with known chromosome numbers in various ploidy levels

\begin{tabular}{|c|c|c|c|c|c|c|}
\hline $\begin{array}{l}\text { Stapeliad } \\
\text { genera }\end{array}$ & $\begin{array}{c}\text { Known number } \\
\text { of species }\end{array}$ & $\begin{array}{l}\% \text { of karyol. } \\
\text { known species }\end{array}$ & $\begin{array}{l}2 x \\
22\end{array}$ & $\begin{array}{c}\text { mbe } \\
4 x \\
44\end{array}$ & $\begin{array}{c}\text { peci } \\
6 x \\
66\end{array}$ & $\begin{array}{l}\text { th } \\
10-12 \mathrm{x} \\
110-132\end{array}$ \\
\hline Caralluma & 120 & 50 & 52 & 3 & 2 & 3 \\
\hline Duvalia & 20 & 55 & 4 & 6 & 1 & - \\
\hline Echidnopsis & 25 & 60 & 13 & 2 & - & - \\
\hline Hoodia & 15 & 33 & 5 & - & - & - \\
\hline Huernia & 60 & 71 & 36 & 6 & 1 & - \\
\hline Orbea & 20 & 45 & 4 & 5 & - & - \\
\hline Orbeopsis & 10 & 60 & 5 & 1 & - & - \\
\hline Piaranthus & 15 & 53 & 7 & 1 & - & - \\
\hline Stapelia & 75 & 44 & 30 & 2 & 1 & - \\
\hline Tridentea & 17 & 47 & 8 & - & - & - \\
\hline Trichocaulon & 15 & 26 & 4 & - & - & - \\
\hline + 11 genera & 47 & 42 & 18 & 2 & - & - \\
\hline Total & 439 & 50 & 186 & 28 & 5 & 3 \\
\hline
\end{tabular}

polysomaty of different kinds can be observed quite often (Reese, 1973) and, in addition, polyploid adventitious roots arising from shoots lying on the ground are rather frequent (Albers, 1979). The occurrence of these cytological and morphological features complicates the determination of the chromosome numbers. Further, in half of the genera polyploid taxa are to be found with chromosome numbers from 44-132, but only in genus Duvalia do polyploids play an important part, whereas in other genera the percentage of polyploidy is rather low.

A comparison of polyploidy levels in stapeliads with that of the non-succulent members of the family shows that the stapeliads have a higher proportion of species with high polyploid levels (Table 3 ).
In Fig. 4 metaphase plates in root tips with different chromosome numbers are to be seen showing no differences in chromosome size between the polyploid levels. The small size of the chromosomes from 1-2 $\mu \mathrm{m}$ makes individual chromosomal identification very difficult. Only Nakamura (1972) and Jash \& Sharma (1972) have attempted studies in the past. Two pairs of chromosomes are clearly distinguishable, one pair as SAT-chromosomes with a NO (nucleolous organization) Region and one pair with a satellite at the distal end of the longer arm. Both pairs seem to occur in many genera as well as in non-succulent ones. The other nine pairs of chromosomes of a diploid species form a graded series with very slight morphological

TABLE 3.-A comparison of the ploidy levels of different groups in Asclepiadaceae

\begin{tabular}{|c|c|c|c|c|c|}
\hline $\begin{array}{l}\text { Asclepiadaceae } \\
\text { group }\end{array}$ & $2 x$ & $\begin{array}{l}\text { Nun } \\
4 \mathrm{x}\end{array}$ & $\begin{array}{l}\text { with } \\
6 \mathrm{x}\end{array}$ & $>6 x$ & $\begin{array}{c}\text { Percent } \\
\text { polyploids }\end{array}$ \\
\hline Stapeliads & 186 & 28 & 5 & 3 & 16 \\
\hline $\begin{array}{l}\text { Non-succulent } \\
\text { members }\end{array}$ & 110 & 11 & - & - & 9 \\
\hline
\end{tabular}




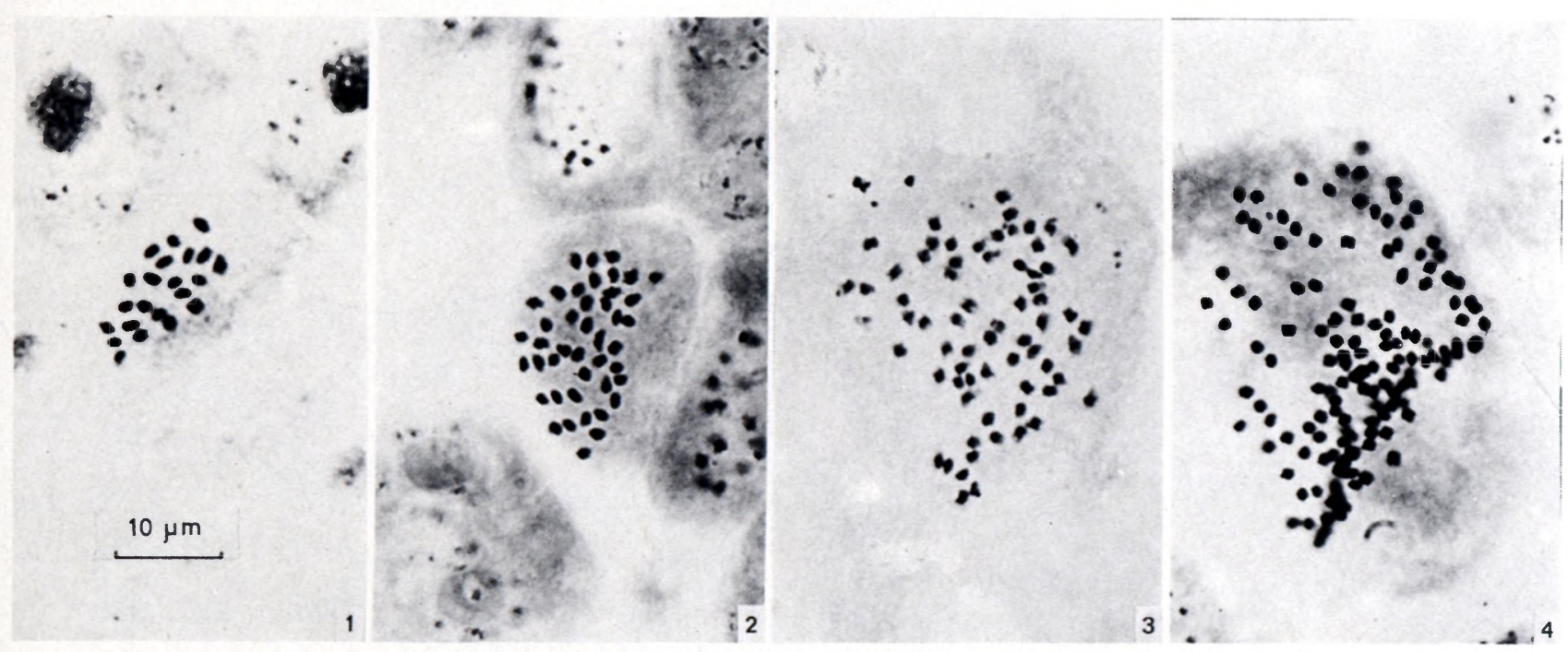

FIG. 1.-Metaphase plates in root tip cells of different species of stapeliads: 1 , Hoodia gordonii, $2 \mathrm{n}=22 ; 2$, Echidnopsis watsonii, $2 \mathrm{n}$ $=44 ; 3$, Duvalia corderoyi, $2 \mathrm{n}=66 ; 4$, Caralluma burchardii var. sventenii, $2 \mathrm{n}=132$.
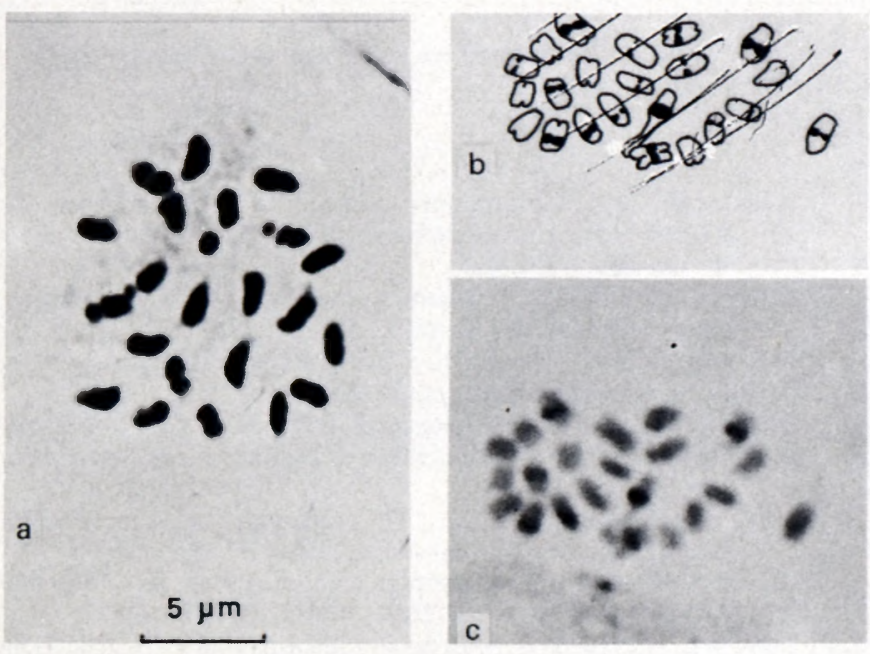

differences and median to subterminal primary constrictions (Fig. 2a).

C-banding greatly facilitates the recognition of individual chromosomes. The metaphase plate of a Caralluma species shows heterochromatic regions on some chromosomes (Fig. $2 b$ \& c). All heterochromatic regions are in centromeric positions. The same heterochromatic distribution is found in the SATchromosomes. In three pairs no heterochromatin is recognizable after Giemsa staining.

The situation in Caralluma is found in many of the species of Asclepiadaceae studied by the author. Further morphological diversity as shown by Jash \& Sharma (l.c.) and Nakamura (l.c.) could scarcely be observed. Karyotype analysis has revealed great similarity in chromosome morphology in all the species of Asclepiadaceae studied. Therefore studies aimed at analysing relationships with the aid of chromosome morphology at a lower taxonomic level (and we have started our studies with the intention of doing so) will hardly be possible.

Though behaviour of the chromosomes in microsporogenesis allows one to draw conclusions about relationship in assumed polyploid hybrids,

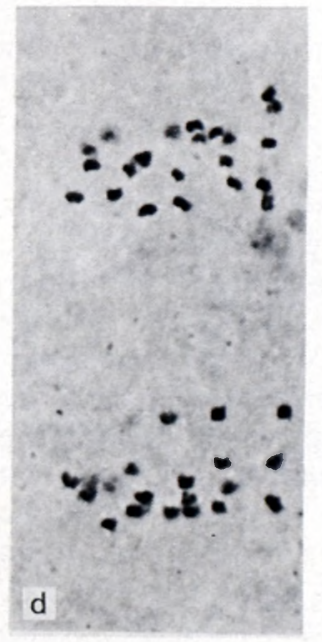

FIG. 2.-a, somatic metaphase plate of Brachystelma dinteri $(2 \mathrm{n}=22)$ with distinct chromosome morphological differentiation; b \& c, C-banded metaphase plate of Caralluma hottentotorum $(2 \mathrm{n}=22)-\mathrm{b}$ is the camera ludica drawing of the microphotograph c: d, meiotic anaphase I of Ceropegia woodii. studies of meiotic divisions in Asclepiadaceae are very rare (Jash \& Sharma, 1972; Reese, 1971) — due to various difficulties. The anaphase I of the tetraploid Ceropegia woodii shows a normal chromosome position (Fig. 2d). Morphological studies of inflorescences have shown that the Caralluma-umbellata-europaea-group in the genus Caralluma, which occurs north of the equator, seems to be the most primitive group (Wertel, 1976). The inflorescence-forms can be derived from a basic type, which is represented in the terminal umbels or umbels near the tip of the stem of some Caralluma species as can be seen, for instance, in $C$. speciosa from Somalia.

In Fig. 3 the presently known species of this Caralluma-group are shown in their regions. A species centre with 29 species, all diploid, is remarkable in the area of South Arabia and East Africa. Hexaploid species appear at the north-west border of the distribution range in Morocco and South Spain, where the stapeliads reach Europe. The highest known chromosome counts are from the two varieties of the endemic Caralluma burchardii on the Canary Islands in which 110,121 and 132 chromosomes are to be found (Albers, 1977, 1981; Borgen, 1974, 1977; Reese 1971.) 


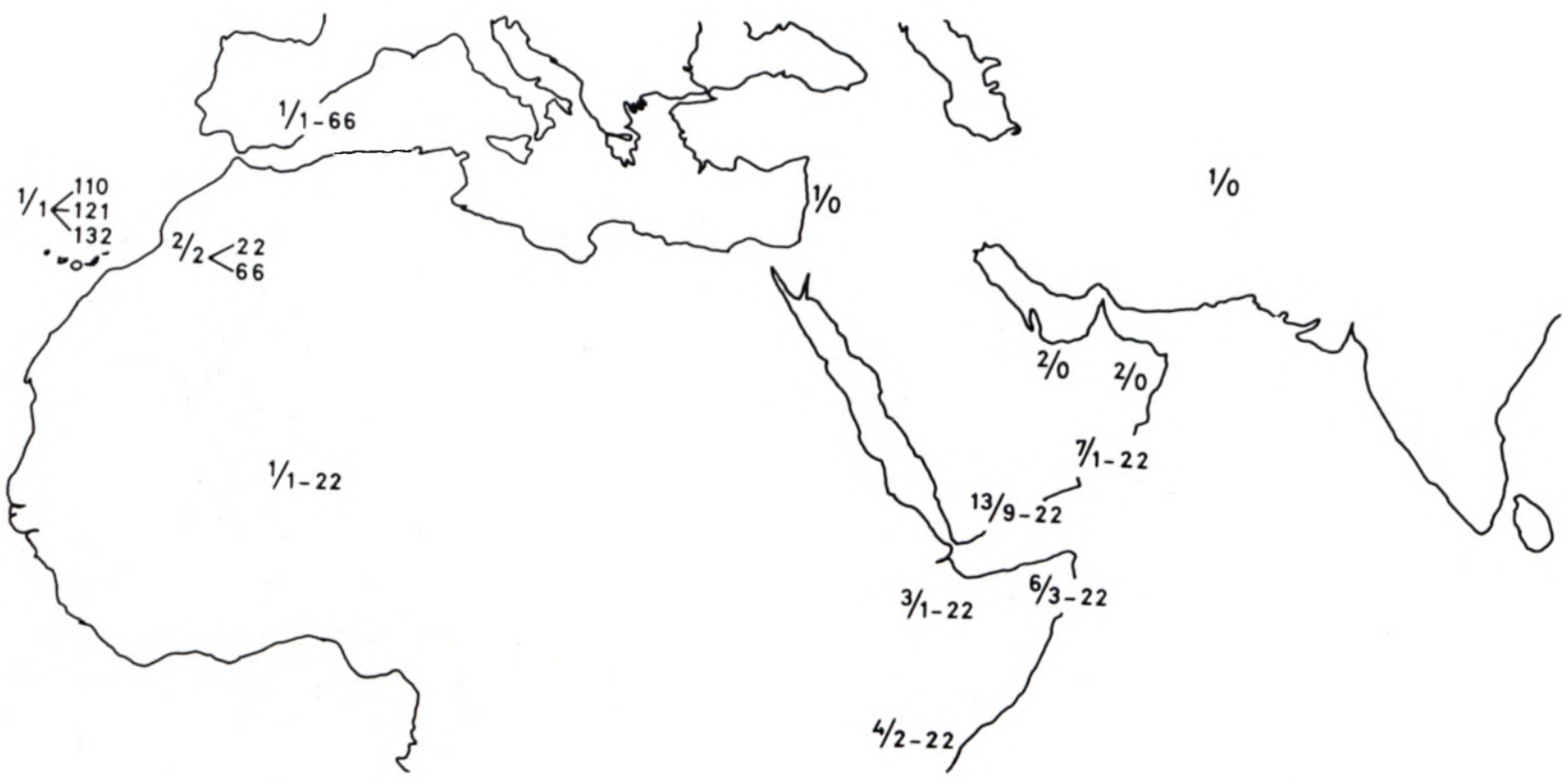

FIG. 3.-The presently known numbers of species of the genus Caralluma north of the equator are to be seen above the diagonal line, the karyologically known under the line, followed by the chromosome number.

If we turn to the east, we come to the species of the Indian Peninsula, which is thought to be the centre of origin of the stapeliads. This supposition may be considered to be supported by the occurrence of Caralluma frerei on this subcontinent, because this species is the only one with leaf-like foliage. Therefore, this species could possibly be regarded as the most primitive species. But karyology cannot support this view for, Caralluma frerei with $2 \mathrm{n}=44$, has a derived chromosome number, which rather conflicts with previous ideas. Unfortunately, counts of the other Indian species are as yet unknown.

\section{REFERENCES}

Albers, F., 1974. Chromosome numbers in the Stapelieae (Asclepiadaceae). In IOPB Chromosome number reports XLIV (A. Löve). Taxon 23: 373-380.

Albers, F., 1975. Chromosome numbers in the Stapelieae (Asclepiadaceae). In IOPB Chromosome number reports XLIX (A. Löve). Taxon 24: 501-516.

Albers, F., 1976. Chromosome numbers in the Stapelieae (Asclepiadaceae). In IOPB Chromosome number reports LI (A. Löve). Taxon 25: 155-164.

Albers, F., 1977. Chromosome numbers in the Stapelieae (Asclepiadaceae). In IOPB Chromosome number reports LVIII (A. Löve). Taxon 26: 557-565.

Albers, F., 1979. Chromosome studies in the Stapeliads. Aloe 17: $85-90$.
AlBers. F., 1981. Chromosome numbers in Asclepiadaceae. In IOPB Chromosome number reports LXX (A. Löve). Taxon 30: $68-80$.

Borgen, L., 1974. Chromosome numbers of Macaronesian flowering plants II. Norw. J. Bot. 21: 195-210.

BORGEN, L., 1977. Check-list of chromosome numbers counted in Macaronesian vascular plants. Oslo.

Brown, R., 1811. On the Asclepiadeae, a natural order of plants separated from the Apocineae of Jussieu. Mem. Wern. nat. Hist. Soc. 1: 12-78.

JASH, M. \& Sharma, A., 1972. Cytology of some Indian Asclepiadaceae. Chromosomes Today 3: 238-247.

LEACH. L. C., 1975. The lectotype species of Stapelia L. and the reinstatement of Orbea Haw. Kirkia 10: 287-291.

LEACH, L. C., 1978. A contribution towards a new classification of Stapelieae (Asclepiadaceae) with a preliminary review of Orbea Haw. and descriptions of three new genera. Excelsa, Taxonomic Ser. 1: 1-75.

LEACH, L. C., 1980. A review of Tridentea Haw. (Asclepiadaceae). Excelsa, Taxonomic Ser. 2: 1-68.

Nakamura, T., 1972. The cytological studies on the chromosome numbers and the karyotypes in some species of genus Stapelia (Asclepiadaceae) II. With English summary. La Kromosomo 87: 2755-2765.

REESE, G., 1971. Untersuchungen über die Chromosomenzahlen der Stapelieae. II. Portug. Acta Biol., Ser. A, 12: 1-23.

SCHILl, R. \& JÄCKEL, U., 1978. Beitrag zur Kenntnis der Asclepiadaceen-Pollinarien. Trop. $u$ subtrop. Pflanzenwelt 22, 122 p. Wiesbaden: Steiner.

Schumann, K., 1895. Asclepiadaceae. In A. Engler \& K. Prantl, Natürl. PflFam. IV: 189-306. Leipzig: Engelmann.

WERTEL, H. P., 1976. Vergleichend-morphologische und entwicklungsgeschichtliche Untersuchungen über Bau und Stellung der Infloreszenzen bei einigen StapelieenGattungen (Fam.: Asclepiadaceae). Trop. u. subtrop. Pflanzenwelt 17.70 p. Wiesbaden: Steiner. 